\title{
Nanostructured magnesium has fewer detrimental effects on osteoblast function
}

\author{
This article was published in the following Dove Press journal: \\ International Journal of Nanomedicine \\ 3 May 2013 \\ Number of times this article has been viewed
}

\section{Lucy Weng \\ Thomas J Webster}

School of Engineering and

Department of Orthopedics,

Brown University, Providence, RI, USA

\begin{abstract}
Efforts have been made recently to implement nanoscale surface features on magnesium, a biodegradable metal, to increase bone formation. Compared with normal magnesium, nanostructured magnesium has unique characteristics, including increased grain boundary properties, surface to volume ratio, surface roughness, and surface energy, which may influence the initial adsorption of proteins known to promote the function of osteoblasts (boneforming cells). Previous studies have shown that one way to increase nanosurface roughness on magnesium is to soak the metal in $\mathrm{NaOH}$. However, it has not been determined if degradation of magnesium is altered by creating nanoscale features on its surface to influence osteoblast density. The aim of the present in vitro study was to determine the influence of degradation of nanostructured magnesium, created by soaking in $\mathrm{NaOH}$, on osteoblast density. Our results showed a less detrimental effect of magnesium degradation on osteoblast density when magnesium was treated with $\mathrm{NaOH}$ to create nanoscale surface features. The detrimental degradation products of magnesium are of significant concern when considering use of magnesium as an orthopedic implant material, and this study identified a surface treatment, ie, soaking in $\mathrm{NaOH}$ to create nanoscale features for magnesium that can improve its use in numerous orthopedic applications.
\end{abstract}

Keywords: nanostructured magnesium, degradation, detrimental effects, osteoblasts

\section{Introduction}

The direct costs of treating orthopedic fractures are approximately 18 billion dollars per year in the US. ${ }^{1}$ These costs are high because initial treatment usually requires follow-up. For example, the initial cost for treating hip fractures ranges from $\$ 30,000$ to $\$ 43,000$, but the follow-up costs in the subsequent year can add an additional $\$ 14,600$. Indirect costs include loss of productivity for patients and caregivers, and can amount to billions of dollars. ${ }^{2}$

Metals are frequently used as orthopedic implants because of their high strength and durability, which makes them suitable for load-bearing applications; however, a disadvantage of using metals is their lack of biodegradability, raising concern about lifelong toxicity. ${ }^{3}$ Many studies have reported on adverse effects caused by permanent metallic implants due to the ongoing release of metallic wear debris. ${ }^{4,5}$ Specifically, Böhler et al examined alumina-blasted cementless titanium-based hip implants with various cobalt alloy bearings and found that there were significant increases in the concentrations of cobalt, chromium, titanium, and aluminum in the tissue surrounding the implant. ${ }^{5}$ In addition, implants in loose sockets allowed alumina particles to accumulate, resulting in early implant failure and pain due to bone necrosis.

\footnotetext{
Correspondence: Thomas J Webster

Department of Chemical Engineering, Northeastern University, Boston,

MA 02II5, USA

Tel +l 6173736585

Fax + I 6173732209

Email th.webster@neu.edu
}

submit your manuscript | www.dovepress.com

Dovepress

http://dx.doi.org/| 0.2147/IJN.S3903| 
As a result of the aforementioned concerns, there has been mounting interest in the use of biodegradable metals such as magnesium, which is the fourth most abundant mineral in the body, in orthopedic implants. ${ }^{6}$ Clearly, wear debris created from a degradable metal will not represent a persistent source of toxicity, and magnesium plays a major role in human health. Approximately $45 \%$ and $5 \%$ of magnesium circulates in intracellular and extracellular fluid, respectively, making it the most abundant intracellular cation in the body. ${ }^{6}$ As a cation, magnesium is a cofactor for over 302 enzymatic reactions and is essential for the synthesis of proteins, antioxidants, carbohydrates, and nucleic acids. ${ }^{7-10}$ Of extreme importance is its role in maintaining genomic stability. In addition to stabilizing the structure of DNA and RNA, magnesium is a cofactor in the repair process to remove DNA damage caused by external mutagens. during replication. ${ }^{10}$ Because of the major role played by magnesium in these metabolic pathways, magnesium deficiency causes an increase in susceptibility to oxidative stress. ${ }^{9}$

Magnesium ions are also needed for the transport of potassium and calcium ions, ${ }^{9}$ which are minerals essential for bone growth. High levels of magnesium cations ensure adequate levels of calcium in the blood to prevent excessive bone resorption. ${ }^{9}$ In fact, studies have shown that a magnesium-restricted diet significantly reduces the levels of serum magnesium and osteocalcin, a protein that affects bone formation. ${ }^{11}$ Furthermore, low magnesium levels increase bone resorption, as seen by elevated levels of parathyroid hormone and deoxypyridinoline in rats with a magnesiumrestricted diet. ${ }^{12}$ These factors result in a decrease in bone mass and bone strength. Similarly, Toba et al showed that magnesium supplementation promotes bone formation (increases in osteocalcin) and prevents bone resorption (decreases in deoxypyridinoline and parathyroid hormone). ${ }^{13}$ They also found a reduction in calcium adsorption, which supports the decrease in bone resorption since lower levels of serum calcium stimulate the release of parathyroid hormone. ${ }^{13}$

Given that magnesium is a mineral essential for bone growth, it can be expected that as a biomaterial it would support bone growth. The impact magnesium has on bone growth was shown further by Hussain et al, who found that adding magnesium calcium phosphate into gelatin sponges containing bone marrow mesenchymal stem cells promoted proliferation and osteogenic differentiation of these cells, and was reflected by higher levels of alkaline phosphatase activity than those seen in sponges containing no magnesium calcium phosphate. ${ }^{15}$ Magnesium has also been shown to have mechanical properties suitable for several orthopedic applications. ${ }^{9}$
However, there are some disadvantages to the use of magnesium as a biodegradable orthopedic implant. Specifically, magnesium degrades in aqueous environments according to the following electrochemical reaction to produce magnesium hydroxide and hydrogen: ${ }^{16}$

$$
\mathrm{Mg}_{(\mathrm{s})}+2 \mathrm{H}_{2} \mathrm{O}_{(\mathrm{aq})} \leftrightarrow \mathrm{Mg}(\mathrm{OH})_{2(\mathrm{~s})}+\mathrm{H}_{2(\mathrm{~g})}
$$

Equations $2-4$ show the partial reactions:

$$
\begin{gathered}
\mathrm{Mg}_{(\mathrm{s})} \leftrightarrow \mathrm{Mg}^{2+}{ }_{\text {(aq) }}+2 \mathrm{e}^{-} \text {(anodic reaction) } \\
2 \mathrm{H}_{2} \mathrm{O}_{(\mathrm{aq})}+2 \mathrm{e}^{-} \leftrightarrow \mathrm{H}_{2(\mathrm{~g})}+2 \mathrm{OH}^{-}{ }_{\text {(aq) }} \text { (cathodic reaction) } \\
\mathrm{Mg}^{2+}{ }_{\text {(aq) }}+2 \mathrm{OH}_{(\mathrm{aq})}^{-} \leftrightarrow \mathrm{Mg}(\mathrm{OH})_{2(\mathrm{~s})} \text { (product formation) }
\end{gathered}
$$

This hydrogenation results in an alkaline environment that raises the $\mathrm{pH}$, which is harmful to cells and decreases cell viability. ${ }^{16,17} \mathrm{~A}$ major research focus is how to slow down the initial corrosion rate during the first 48 hours of implantation in order to allow bone to form on the magnesium which will help to decrease the corrosion process. ${ }^{18-20}$

Along these lines, efforts have been made recently to develop magnesium with nanoscale surface features that can increase immediate bone formation to decrease or compensate for the negative effects of magnesium corrosion. ${ }^{21}$ Nanostructured magnesium has unique characteristics compared with its bulk counterpart, including increased grain boundary exposure, surface to volume ratio, surface roughness, and surface energy. Previous studies have shown that treating magnesium with $\mathrm{NaOH}$ results in nanoscale surface features that increase osteoblast adhesion, proliferation, alkaline phosphatase activity, and calcium deposition. ${ }^{21}$ However, it has not been determined as yet if the degradation of magnesium is altered by creating nanoscale surface features on magnesium via soaking in $\mathrm{NaOH}$ to influence osteoblast density. Thus, the objective of the present study was to determine the influence of degradation of nanostructured magnesium, created by soaking in $\mathrm{NaOH}$, on the functions of osteoblasts.

\section{Materials and methods Creating nanorough magnesium}

Magnesium ribbon (Alfa Aesar, Ward Hill, MA) $0.30 \mathrm{~cm} \times 0.015 \mathrm{~cm}$ was cut into pieces $1.4 \mathrm{~cm}$ in length. $\mathrm{NaOH}$ pellets (Fisher Scientific, Fairlawn, NJ) were dissolved in deionized water to produce solutions of $1 \mathrm{~N}, 5 \mathrm{~N}$, and $10 \mathrm{~N}$ concentration. The magnesium pieces were treated with each concentration of $\mathrm{NaOH}$ for 20 minutes (1N 20 minutes, 
$5 \mathrm{~N} 20$ minutes, and $10 \mathrm{~N} 20$ minutes [1N20, 5N20, and 10N20, respectively) at room temperature. The samples were then washed several times with phosphate-buffered solution, and the rinsed solution was tested with $\mathrm{pH}$ paper to ensure that all the excess base was removed. The magnesium pieces were left to dry in a tissue culture hood and then stored in a desiccator to prevent any potential reaction with moisture from the air. The samples were sterilized by exposure to ultraviolet light.

\section{Material characterization}

\section{Scanning electron microscopy}

Scanning electron microscopy was performed using a field emission scanning electron microscope (LEO $1530 \mathrm{VP}$ FE-4800, Zeiss, Peabody, MA) to determine if nanoroughness was produced from the $\mathrm{NaOH}$ treatment.

\section{Atomic force microscopy}

Atomic force microscopy was performed using an Asylum-1 MFP-3D system (Asylum Research, Santa Barbara, CA) to examine the topography of the $\mathrm{NaOH}$-treated magnesium samples. A $1 \mu \mathrm{m} \times 1 \mu \mathrm{m}$ area was scanned, and root mean square values were obtained to quantify the surface roughness.

\section{Electron spectroscopy for chemical analysis}

Electron spectroscopy for chemical analysis was performed using a 5500 multitechnique surface analyzer system (Perkin Elmer, Waltham, MA). The surfaces of the $\mathrm{NaOH}$-treated samples and nontreated control were analyzed to determine their chemical composition.

\section{Contact angle measurements}

Contact angle measurements to determine surface hydrophilicity were obtained using a Krüss easy drop contact angle instrument (A Krüss Optronic GmbH, Hamburg, Germany) connected to the Drop Shape Analysis program version 1.8. A $2.5 \mu \mathrm{L}$ drop of water was produced on the surface and contact angles were obtained after a specified time. Measurements were acquired after 60 seconds of drop placement for all treated samples. Contact angles were acquired on three random fields for each sample. All measurements were run in triplicate.

\section{Measurements of $\mathrm{pH}$}

The supernatants from the cell studies described in the next column were collected after 4 hours of incubation, and for the proliferation studies they were collected every 24 hours up to 120 hours and tested using a standard $\mathrm{pH}$ meter.

\section{Cell studies}

Healthy human osteoblasts (CRL-11372, American Type Culture Collection, Manassas, VA) were cultured in Dulbecco's modified Eagle's medium, high glucose (HyClone, Logan, UT; Gibco, Grand Island, NY), supplemented with $10 \%$ fetal bovine serum and $1 \%$ penicillin-streptomycin in a $37^{\circ} \mathrm{C}$, humidified $5 \% \mathrm{CO}_{2}$ environment. Generation 3 and 4 cells were used for all cell experiments. Polystyrene tissue culture wells without magnesium samples were used as controls. The WST-1 (2-(4-iodophenyl)-3-(4-nitrophenyl)-5-(2,4-disulfophenyl)2H-tetrazolium) assay (Roche, Basel, Switzerland) was used to determine the cell density in all samples. For cell adhesion, cells were seeded at $3500 \mathrm{cells} / \mathrm{cm}^{2}$ per substrate and allowed to adhere for 4 hours in a $37^{\circ} \mathrm{C}$, humidified $5 \% \mathrm{CO}_{2}$ environment. After the 4-hour cell adhesion assay, $100 \mu \mathrm{L}$ of WST-1 was added to each well.

The present study determined cell density on both the magnesium and the tissue culture polystyrene surrounding the magnesium, so for the WST-1 assay, the magnesium samples were removed from the tissue culture polystyrene at the end of the experiment (then exposed to WST-1 assay reagents) to determine differences in density between the two samples. Determining the osteoblast density on the polystyrene was helpful to determine the effect of magnesium degradation on the osteoblast density on the juxtaposed polystyrene tissue culture plate. For this, the tetrazolium was cleaved into a soluble formazan by glycolytic production of nicotinamide adenine dinucleotide phosphate oxidase in viable cells. After 2 hours of incubation, the solutions were transferred to a clean 96-well plate and absorbance was measured with a microplate reader at $440 \mathrm{~nm}$. All experiments were completed in triplicate and repeated three times.

A similar process to that described above was used for cell proliferation, except that the cells were seeded at $2000 \mathrm{cells} / \mathrm{cm}^{2}$ per substrate and allowed to proliferate for 24,72 , and 120 hours in a $37^{\circ} \mathrm{C}$, humidified $5 \% \mathrm{CO}_{2}$ environment. The medium in the wells were removed and replaced with fresh Dulbecco's modified Eagle's medium every 24 hours for all substrates. After the specified periods, the samples were washed with phosphate-buffered solution and transferred to fresh medium in a clean 24-well plate. The WST-1 assay was conducted as described above to determine cell viability. Experiments were conducted in triplicate and repeated three times. For all experiments, differences between means were evaluated using the Student $t$-test. 


\section{Results}

\section{Characterization of magnesium}

The surfaces of the magnesium samples treated with $\mathrm{NaOH}$ were examined using a scanning electron microscope (Figure 1). As expected, increased roughness at the nanoscale level was seen on all the treated samples compared with the controls, and this roughness increased with increasing $\mathrm{NaOH}$ concentration. The surface roughness was also examined and quantified by atomic force microscopy, which supported the results of scanning electron microscopy (Table 1 and Figure 2). Root mean square values increased in the treated samples with increasing $\mathrm{NaOH}$ concentration. It is important to note that, while $\mathrm{NaOH}$ degrades magnesium, because the treatment occurred in a closed container, the change in surface roughness may be due to a combination of degradation and deposition of ions. That is, due to the process followed in this study, after treatment with a strong base, rapid rinsing in phosphate-buffered solution, which causes a rapid $\mathrm{pH}$ change, may cause ion precipitation (such as calcium) on the substrate surface.

The surface wettability of the magnesium samples treated with $\mathrm{NaOH}$ was characterized by contact angle measurements. The results showed that all of the $\mathrm{NaOH}$-treated samples were more hydrophilic (ie, had more surface energy) compared with the untreated magnesium (Table 2). Among the nanorough samples, the most aggressive treatment, ie, 10N30,
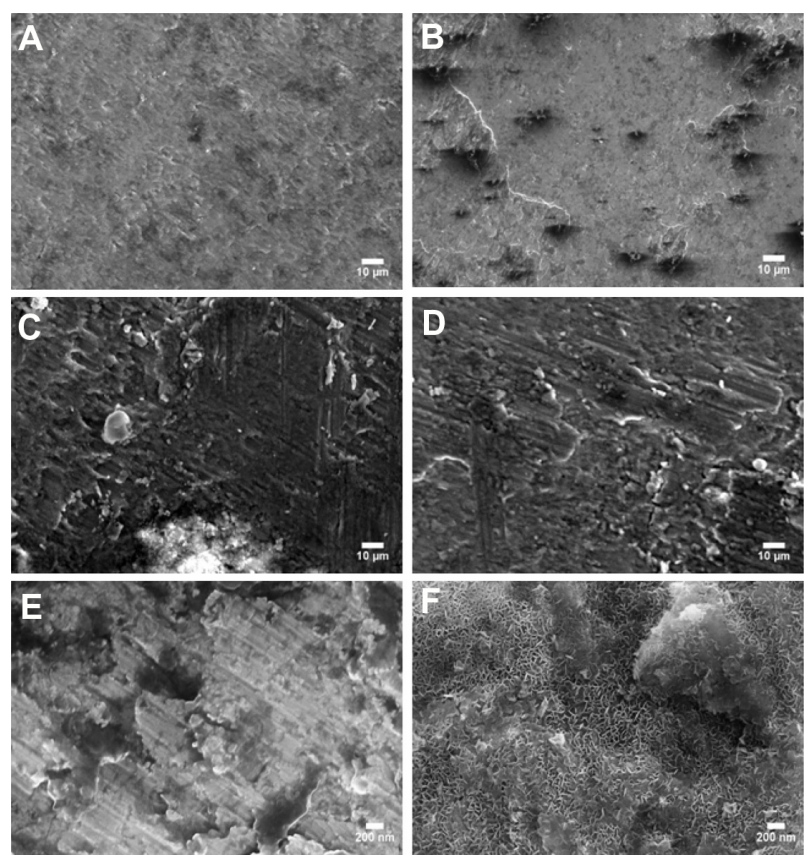

Figure I Surface morphology of magnesium treated with $\mathrm{NaOH}$ viewed under scanning electron microscopy at $2000 \times$ for (A) control (untreated), (B) IN20, (C) 5N20, and (D) 10 N20, and at $80,000 \times$ for (E) control (untreated), and (F) I0N20. Notes: Scale bars represent $10 \mu \mathrm{m}(\mathrm{A}-\mathrm{D})$ and $200 \mathrm{~nm}$ (E and F).
Table I Atomic force microscopic root mean square values of untreated (control) and $\mathrm{NaOH}$ treated magnesium

\begin{tabular}{ll}
\hline Substrate & $\begin{array}{l}\text { Root mean } \\
\text { square value }(\mathbf{n m})\end{array}$ \\
\hline Control (untreated) magnesium & $32.89 \pm 2.64$ \\
IN20 & $26.68 \pm 0.55$ \\
$5 \mathrm{~N} 20$ & $34.81 \pm 0.70$ \\
ION20 & $37.15 \pm 1.54$ \\
\hline
\end{tabular}

caused a significant decrease in the contact angle compared with the mildest treatment of $1 \mathrm{~N} 10(P<0.001)$. As will be described, a change in wettability can alter degradation to influence the behavior of osteoblasts.

Lastly, the treated and untreated magnesium samples were analyzed by electron spectroscopy to determine the chemical composition of the surfaces (Table 3). All the samples had peaks for magnesium $(\mathrm{Mg} 2 \mathrm{~s})$, oxygen $(\mathrm{O} 1 \mathrm{~s})$, and carbon $(\mathrm{C} 1 \mathrm{~s}) .{ }^{21}$ However, a notable difference between the control and all the treated samples was the carbon peak. The control had two distinct peaks, one at around $289 \mathrm{eV}$ and the other at around $291 \mathrm{eV}$. Most of the treated samples only had one peak at $289 \mathrm{eV}$, and for the few that had two peaks, the second peak was much smaller and lower in intensity. One possible explanation for this is that the degradation from $\mathrm{NaOH}$ removed some of the carbon from the surface. Another possible explanation is carbon contamination, such as with $\mathrm{MgCO}_{3}$, which could be removed in future studies via an alcohol wash. Another marked difference between the treated and control samples is the increased amount of oxygen on the treated samples, which could also be attributed to treatment with $\mathrm{NaOH}$ and formation of oxides. Interestingly, palladium (Pd3d) was also found on some (but not all) of the samples, which most likely was one of the trace metals that remained during the manufacturing process. Even magnesium that is labeled as commercially pure usually only contains $99.95 \%$ pure magnesium. Importantly, electron spectroscopy for chemical analysis showed some key chemical differences between the treated and non-treated magnesium, specifically, less carbon and greater oxygen when magnesium was treated with $\mathrm{NaOH}$. However, no sodium was measured, perhaps due to the washing after treatment.

\section{Change in $\mathrm{pH}$ during magnesium degradation}

The $\mathrm{pH}$ values in the cell culture supernatant from the aforementioned osteoblast adhesion and proliferation experiments were measured to determine the effect that changes in $\mathrm{pH}$ had on cell density (Figure 3). pH values were also obtained 
A
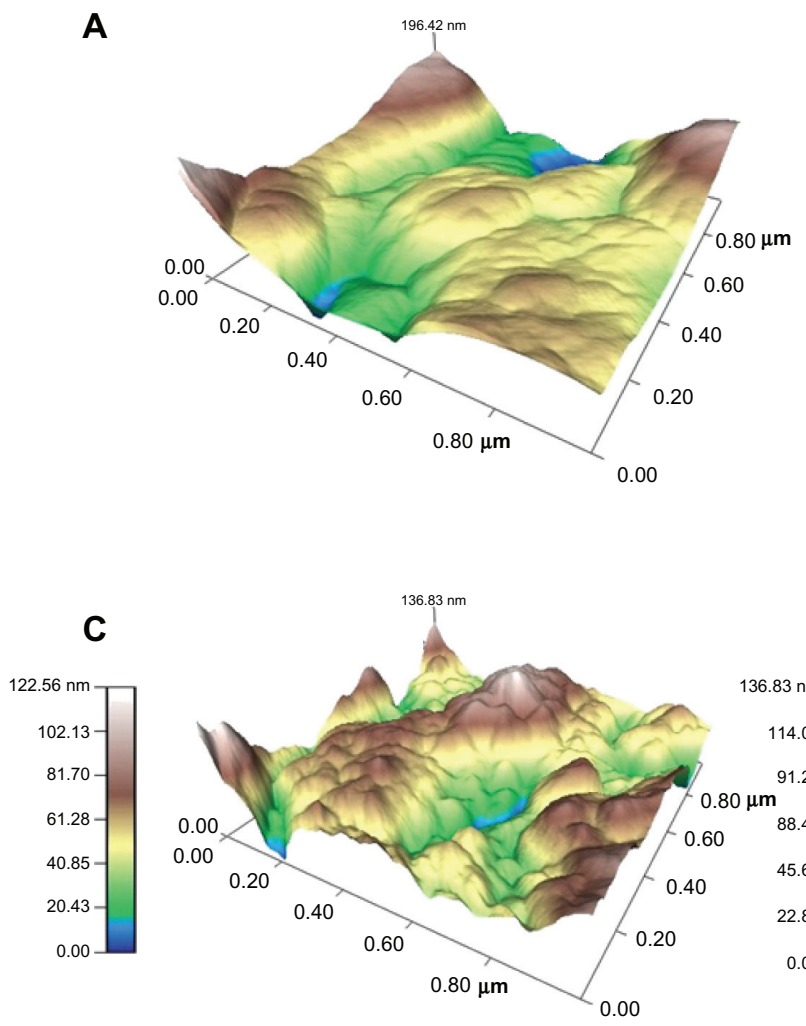

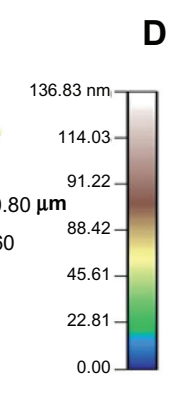

B
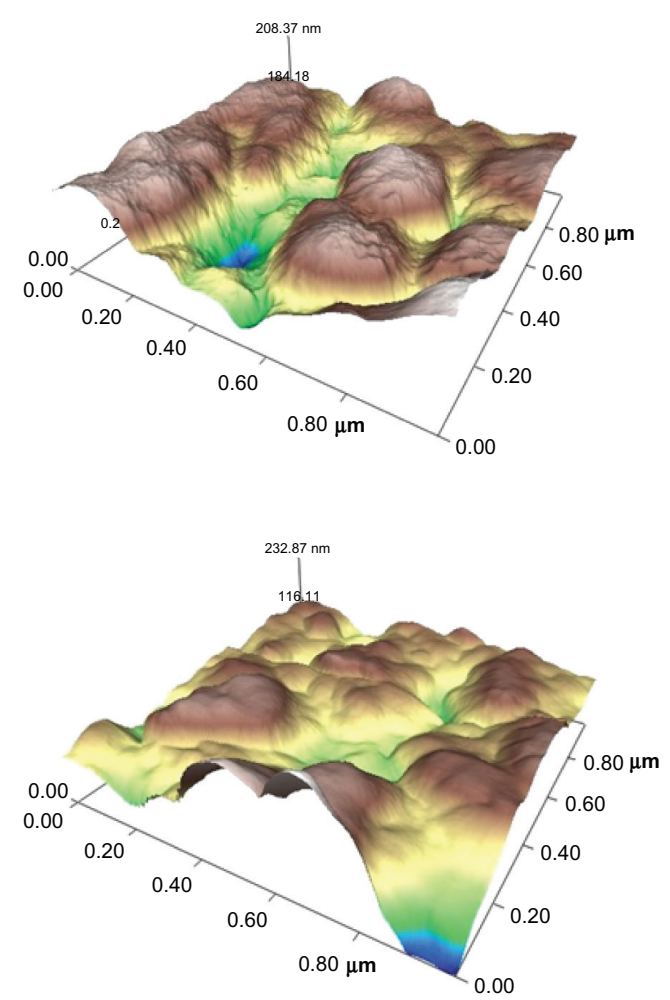

Figure 2 Surface topography of the magnesium samples scanned by atomic force microscopy for (A) control (untreated), (B) I N20, (C) 5 N20, and (D) I0 N20.

for the nontreated control sample (magnesium with no cells) to determine the contributing effect of cells on $\mathrm{pH}$ levels. The values shown are the differences between the original medium and the culture supernatant after each time point. The cellular supernatant for polystyrene showed a slight decrease in $\mathrm{pH}$, which can be expected because cells generally thrive at slightly alkaline $\mathrm{pH}$ levels, so the extracellular $\mathrm{pH}$ levels would become lower to maintain equilibrium. The magnesium-no cells showed a significant $\mathrm{pH}$ increase as well, while the control with cells did not, suggesting that the presence of cells helped to maintain a $\mathrm{pH}$ balance. The other samples did not show a major change in $\mathrm{pH}$ after 4 hours. Of interest is the fact that the $\mathrm{pH}$ decreased in the $1 \mathrm{~N} 20$ sample which, as will be discussed, was found to have one of the highest cell viabilities (Figure 4).

However, the greatest change in $\mathrm{pH}$ occurred after 24 hours. As expected, after 24 hours, the magnesium-no

Table 2 Contact angles for the magnesium samples

\begin{tabular}{ll}
\hline Substrate & $\begin{array}{l}\text { Contact angle } \\
\text { (degrees) }\end{array}$ \\
\hline Control (untreated) magnesium & $89.8 \pm 2.1$ \\
IN20 & $39.5 \pm 1.1$ \\
5N20 & $36.1 \pm 0.9$ \\
ION20 & $28.4 \pm 0.8$ \\
\hline
\end{tabular}

cells showed the greatest increase in $\mathrm{pH}$. Among the magnesium substrates, all of the samples had increased $\mathrm{pH}$ values $(P<0.01$ for $5 \mathrm{~N} 20$ and $10 \mathrm{~N} 20, P<0.001$ for control and $1 \mathrm{~N} 20)$. Of interest is the fact that the control sample produced the least change in $\mathrm{pH}$ compared with the treated $1 \mathrm{~N} 20,5 \mathrm{~N} 20$, and $10 \mathrm{~N} 20$ samples $(P<0.01, P<0.05$, and $P<0.01$, respectively). The $\mathrm{pH}$ change for the $5 \mathrm{~N} 20$ sample was significantly less than that observed for the $1 \mathrm{~N} 20$ and 10N20 samples $(P<0.01)$.

At 48 hours, the $\mathrm{pH}$ values were still all significantly higher $(P<0.05)$, except for the cells on polystyrene, which again decreased. The changes in $\mathrm{pH}$ for the magnesium samples became smaller and actually decreased at 72 hours for all samples except the magnesium-no cells. This substrate resulted in a significant increase $(P<0.05)$, showing again that the presence of cells helped to maintain $\mathrm{pH}$ levels.

Table 3 Percent composition of various elements on magnesium samples as determined by electron spectroscopy for chemical analysis

\begin{tabular}{lllll}
\hline Substrate & Magnesium & Oxygen & Carbon & Palladium \\
\hline Control (untreated) & 17.72 & 39.42 & 42.68 & \\
IN20 & 19.89 & 59.95 & 18.82 & 1.34 \\
5N20 & 20.85 & 60.27 & 18.85 & 0.03 \\
ION20 & 21.62 & 59.5 & 18.89 & \\
\hline
\end{tabular}




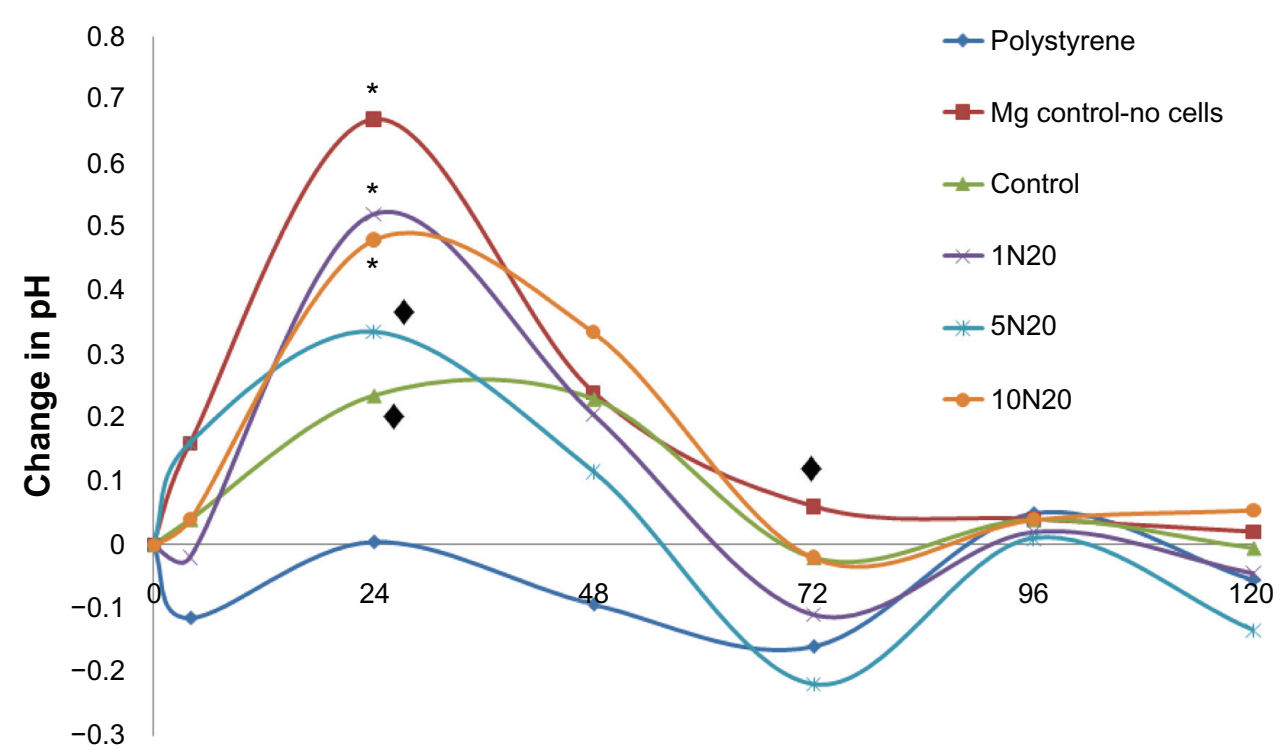

Hours

Figure 3 Changes in $\mathrm{pH}$ values of the culture media at 4, 24, 48, 72, 96, and I 20 hours of osteoblast proliferation on polystyrene, magnesium controls without cells (Mg-control-no cells), untreated magnesium controls as well as magnesium treated with IN20, 5N20, and I0N20.

Note: A decrease in $\mathrm{pH}$ was observed for the polystyrene $\left(\bullet^{P}<0.05\right)$. A significant increase in $\mathrm{pH}$ was observed at 24 hours for all samples except the polystyrene $(* P<0.00 \mathrm{I} ; \cdot P<0.0 \mathrm{I})$. As expected, by 72 hours, only the $\mathrm{Mg}$-control-no cells showed a significant increase in $\mathrm{pH}(\mathrm{P}<0.0 \mathrm{I})$. Values represent the difference between the original $\mathrm{pH}$ of the medium and the $\mathrm{pH}$ obtained after 4 hours for $\mathrm{n}=3$.

For the other samples, a decrease in $\mathrm{pH}$ was observed for the polystyrene, $1 \mathrm{~N} 20$, and $5 \mathrm{~N} 20(P<0.01, P<0.05$, and $P<0.01$, respectively). Little change was observed after 96 hours, suggesting that degradation had slowed. After 120 hours, there was also relatively no change in $\mathrm{pH}$, except for an observed decrease for the 5N20 sample $(P<0.05)$. Such results demonstrated a clear change in degradation and $\mathrm{pH}$ values for the untreated versus $\mathrm{NaOH}$-treated magnesium samples.

\section{Osteoblast density in the presence of magnesium}

Most importantly, our results showed an increased osteoblast density on magnesium treated with 10 N20 compared with any of the other magnesium samples (Figure 4). Specifically, the cell density on the polystyrene substrate was around 3200 cells $/ \mathrm{cm}^{2}$ compared with the cell density on magnesium, which ranged from $1605 \mathrm{cells} / \mathrm{cm}^{2}$ (control) to $2515 \mathrm{cells} / \mathrm{cm}^{2}$ (10N20 treatment). Also shown is the osteoblast density on polystyrene in the presence of magnesium in order to demonstrate the effect of magnesium degradation on the surrounding cell density. As expected, the cell density on the magnesium control, $1 \mathrm{~N} 20$, and $5 \mathrm{~N} 20$ were all significantly lower than the cell adhesion on the polystyrene substrate without the magnesium ( $P<0.001, P<0.02$, and $P<0.02$, respectively). However, importantly, no significant difference was observed for the cell density on the polystyrene alone compared with the polystyrene in the presence of 10N20 magnesium. This result suggests for the first time that after 4 hours, magnesium treated with $10 \mathrm{~N} 20$ did not have an adverse effect on the density of surrounding cells, whereas all other magnesium samples did have an adverse effect.

After longer time periods, the results were similar in that treating magnesium with $\mathrm{NaOH}$ at higher concentrations for longer periods of time minimized the negative influence of magnesium degradation on surrounding osteoblasts (Figure 5). Specifically, as expected, polystyrene alone had osteoblast densities of 3610, 6935, and $24231 \mathrm{cells} / \mathrm{cm}^{2}$ after 24,72 , and 120 hours, respectively, which was higher than for the polystyrene in the presence of any magnesium for all time periods $(P<0.001)$. This shows that magnesium degradation had an adverse effect on osteoblast proliferation. However, after 72 and 120 hours, osteoblast density was again greater on the polystyrene with magnesium treated with stronger concentrations and times of $\mathrm{NaOH}$, indicating less of a detrimental effect of magnesium degradation on surrounding osteoblasts upon exposure to greater $\mathrm{NaOH}$ concentrations; with the caveat that osteoblast density was greater on the polystyrene in the presence of magnesium treated with $5 \mathrm{~N}$ compared with $10 \mathrm{~N} \mathrm{NaOH}$ for 20 minutes, which requires further investigation. Lastly, in contrast with the adhesion results, no difference in osteoblast density after 48,72 , and 120 hours was observed on the magnesium treated with different concentrations and times of $\mathrm{NaOH}$, 


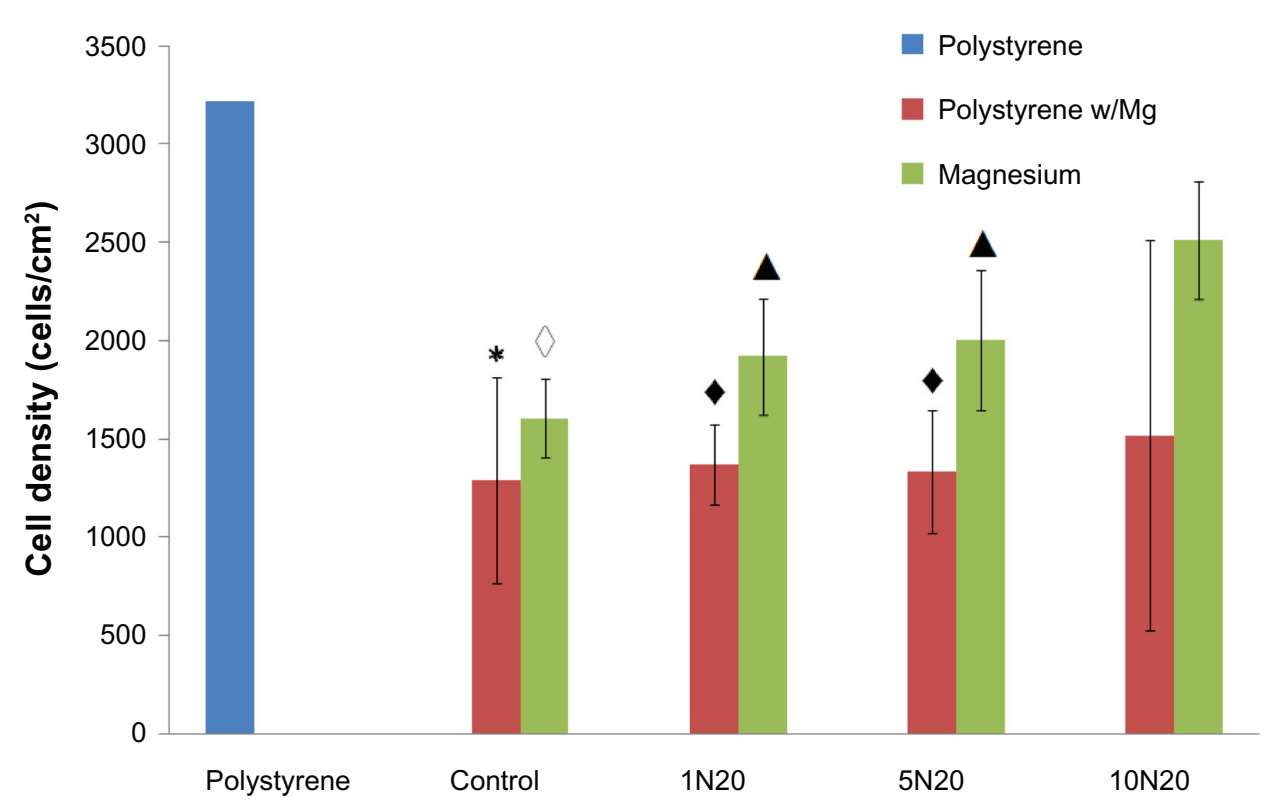

Figure 4 Greater osteoblast adhesion density on polystyrene when cultured in the presence of $\mathrm{NaOH}$-treated nanostructured magnesium than untreated control magnesium. Notes: Compared with the polystyrene substrate alone, all the other samples except I0N20 decreased osteoblast adhesion (*P $<0.05 ; \bullet P<0.0$ I; ${ }^{\circ} P<0.00$ I; ${ }^{\wedge} P<0.02$ ). Values represent the mean \pm standard deviation for $n=3$.

which requires further investigation, given that previous studies have demonstrated greater alkaline phosphatase and calcium deposition by osteoblasts on magnesium treated with greater concentrations and time of $\mathrm{NaOH} \cdot{ }^{21}$ It is known that osteoblasts slow down proliferation as they begin to secrete extracellular matrix proteins, which may account for this observation. ${ }^{1}$

\section{Discussion}

As mentioned, one of the greatest challenges when using magnesium as a biomaterial stems from its fast corrosion rate that creates the reaction: $\mathrm{Mg}_{(\mathrm{s})}+2 \mathrm{H}_{2} \mathrm{O}_{(\text {aq) }} \leftrightarrow$ $\mathrm{Mg}(\mathrm{OH})_{2(\mathrm{~s})}+\mathrm{H}_{2(\mathrm{~g})}$. This releases $\mathrm{OH}^{-}$ions resulting in an alkaline $\mathrm{pH}$ which can clearly be detrimental to cell viability. Numerous studies have highlighted the fact that degradation of magnesium may be a clinical problem, but modification of the magnesium surface can minimize such effects by promoting early cellular events. ${ }^{3,22,23}$ Specifically, one study created two types of magnesium surfaces, ie, a commercial magnesium that contained an oxide layer via a natural reaction with air (labeled $\mathrm{Mg} \_\mathrm{O}$ ) and a smoother polished magnesium (labeled Mg_P). ${ }^{3}$ As with other studies, it was reported that the same cell culture medium as used here, ie, Dulbecco's modified Eagle's medium, degrades magnesium. Of interest was the fact that the Mg_O produced surface pitting within 72 hours, while the Mg_P did not start to form pits until after 7 days. The study also showed formation of oxides after incubation with Dulbecco's modified Eagle's medium, with small particulate matter and formation of needle-like structures along the edges.

Alternatively, treating magnesium with $\mathrm{HNO}_{3}$ has been shown to increase degradation, because the $\mathrm{H}^{+}$ions from the acid can react with the $\mathrm{OH}^{-}$ions produced as magnesium degrades, thus promoting more formation of $\mathrm{OH}^{-}$and increased degradation. ${ }^{1,3}$ This has also been shown by the increased degradation of magnesium in simulated body fluid, which contains large amounts of tris- $\mathrm{HCl}$, and so more $\mathrm{H}^{+}$to consume the $\mathrm{OH}^{-}$. Lastly, it has been shown that increased grain boundaries and structural defects promote corrosion if impurities accumulate in these areas. ${ }^{17}$

As evident in this study, treating magnesium samples with $\mathrm{NaOH}$ resulted in increased formation of an oxide layer. This layer can be beneficial because it provides a protective coating that slows degradation to decrease the impact of detrimental magnesium degradation products. Although not accomplished with $\mathrm{NaOH}$ treatment, other studies have demonstrated that oxide layers on magnesium can slow the degradation of magnesium. ${ }^{1,3}$ Specifically, one study examined the degradation of three different magnesium samples, ie, magnesium that was heat-treated to produce a surface oxide layer, heat-treated magnesium that was strained to $9 \%$ to mimic natural body stresses, and polished magnesium. ${ }^{3}$ The authors found that the stained magnesium with an oxide layer degraded faster than the non-strained magnesium with an oxide layer, which makes sense because the oxide layer was weakened and more prone to corrosion attack when strained. However, more 


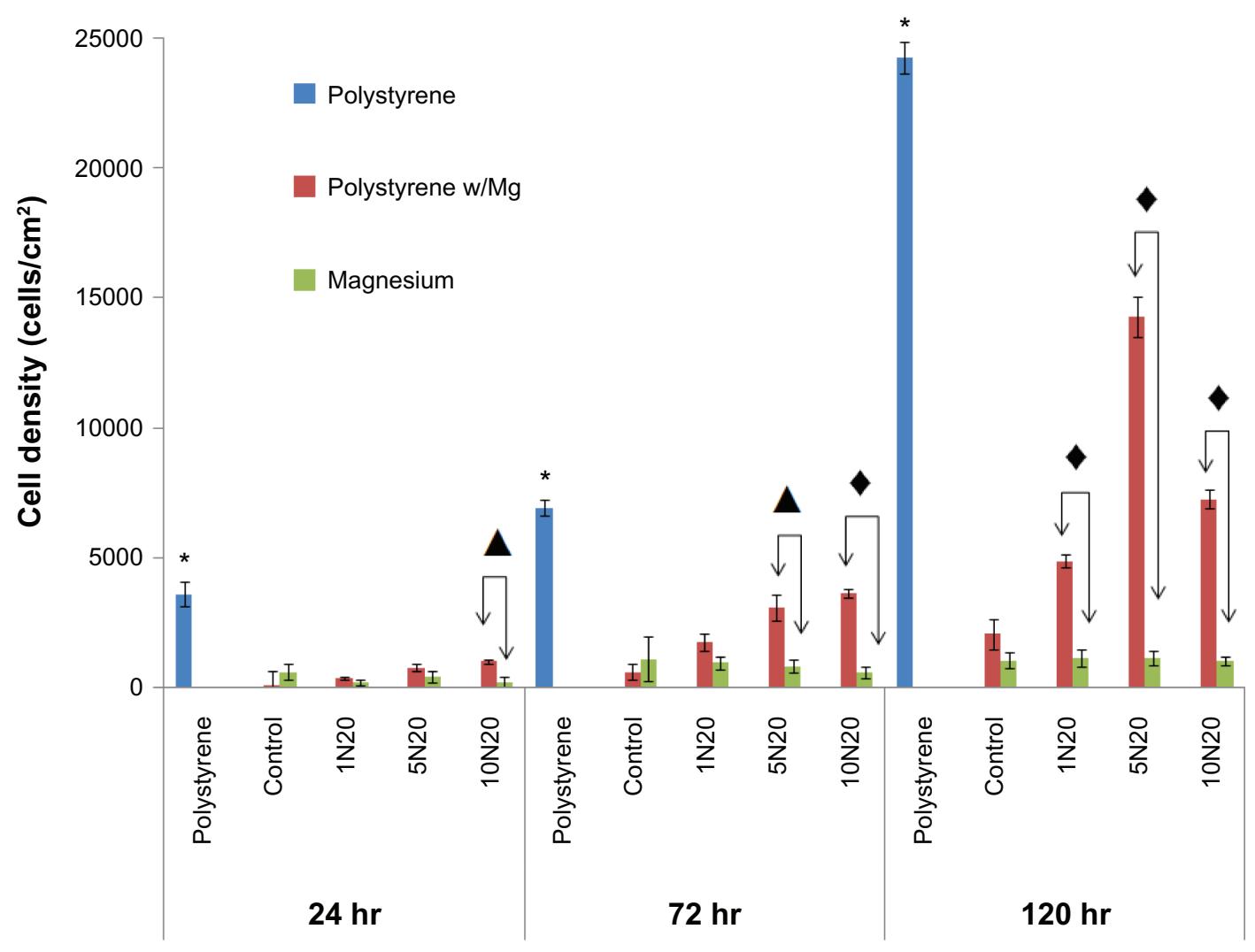

Figure 5 Greater osteoblast density on polystyrene when cultured in the presence of $\mathrm{NaOH}$-treated nanostructured magnesium than untreated control magnesium. Notes: Cell density on the polystyrene substrates was significantly greater than on the other substrates for all proliferation times $(* P<0.05)$. Values represent the mean \pm standard error of the mean for $\mathrm{n}=3 ; \bullet \mathrm{P}<0.05 ; \bullet P<0.001$.

importantly, the potential protection of this oxide layer was demonstrated because the non-strained magnesium had a slower degradation rate than the polished magnesium.

$\mathrm{The} \mathrm{NaOH}$ treatment used in the present study produced an oxide layer and served another important purpose of creating nanoscale surface features known to promote osteoblast function, ${ }^{24-27}$ which compensated for the detrimental magnesium degradation products. As mentioned already, previous studies have reported increased alkaline phosphatase activity and calcium deposition by osteoblasts on magnesium treated with increasing times and concentrations of $\mathrm{NaOH} .{ }^{21}$

The most important finding of the present study was the osteoblast density observed on the polystyrene in the presence of magnesium samples, providing evidence of the influence of magnesium degradation on surrounding osteoblasts. After 72 hours, the cell density was significantly higher compared with that at 24 hours for the $1 \mathrm{~N} 20,5 \mathrm{~N} 20$, and $10 \mathrm{~N} 20$. The cells continued to proliferate in a manner similar to that observed for cells seeded onto standard polystyrene (with no magnesium) and an increase was again observed after 120 hours compared with 72 hours for the $1 \mathrm{~N} 20,5 \mathrm{~N} 20$, and $10 \mathrm{~N} 20(P<0.001)$. This suggests that while magnesium degradation limited growth on their actual surface (perhaps because they were secreting extracellular matrix proteins), the cells were still able to proliferate in the area immediately surrounding the degradation site. This observation is supported by other studies that have found increased bone growth in the area surrounding a degrading magnesium scaffold. ${ }^{22}$ Specifically, Witte et $\mathrm{al}^{22}$ studied the in vivo morphology of magnesium rods implanted into guinea pigs and found that one rod had severe degradation and pitting, but had direct contact with newly formed bone. This contrasted sharply with osteoblasts on polystyrene in the presence of control magnesium. That is, while the osteoblasts on the polystyrene in the presence of nanorough magnesium continued to proliferate, the cells on the polystyrene in the presence of untreated magnesium controls showed much slower proliferation, again demonstrating the harmful effects of magnesium degradation products on osteoblasts. Our study demonstrated a method of compensating for such harmful degradation products by treating magnesium with $\mathrm{NaOH}$.

\section{Conclusion}

Previous studies have shown that one method of increasing nanosurface roughness on magnesium is via soaking 
magnesium in $\mathrm{NaOH}$. This study demonstrates for the first time a less detrimental effect of magnesium degradation on osteoblast density when magnesium is treated with $\mathrm{NaOH}$. Given that the detrimental degradation products of magnesium are significant concerns when considering use of magnesium as an orthopedic implant material, this study identified a surface treatment (soaking in $\mathrm{NaOH}$ to create nanoscale features and an oxide layer) for magnesium that can improve its use for numerous orthopedic applications.

\section{Acknowledgment}

The authors would like to thank the Hermann Foundation for funding this research.

\section{Disclosure}

The authors report no conflicts of interest in this work.

\section{References}

1. Liu H. Bioinspired nanocomposites for orthopedic applications. In: Webster TJ, editor. Nanotechnology for the Regeneration of Hard and Soft Tissues. Toh Tuck Link, Singapore: World Scientific Publishing Company; 2007.

2. Smith R. Bone Health and Osteoporosis: A Report of the Surgeon General. Rockville, MD: US Department of Health and Human Services, Public Health Service, Office of the Surgeon General; 2004.

3. Liu H. Biodegradable metals and responsive biosenors for musculosketal applications. In: Webster TJ, editor. Nanotechnology Enabled In Situ Sensors for Monitoring Health. New York, NY: Springer Science; 2011.

4. Wolner C, Nauer GE, Trummer J, Putz V, Tschegg S. Possible reasons for the unexpected bad biocompatibility of metal-on-metal hip implants. Mat Sci Eng. 2006;26:34-40.

5. Bohler M, Kanz F, Schwarz B, et al. Adverse tissue reactions to wear particles form Co-alloy articulations, increased by alumina-blasting particle contamination from cementless Ti-based total hip implants a report of seven revisions with early failure. J Bone Joint Surg $\mathrm{Br}$. 2002;84B:128-136.

6. Arnaud MJ. Update on the assessment of magnesium status. Br J Nutr. 2008;99:S24-S36.

7. Fox CH, Timm EA, Smith SJ, Touyz RM, Bush EG, Wallace PK. A method for measuring intracellular free magnesium concentration in platelets using flow cytometry. Magnes Res. 2007;20:200-207.

8. Saris NEL, Mervaala E, Karppanen H, Khawaja JA, Lewenstam A. Magnesium - an update on physiological, clinical and analytical aspects. Clin Chim Acta. 2000;294:1-26.

9. Okuma T. Magnesium and bone strength. Nutrition. 2001;17:679-680.
10. Hartwig A. Role of magnesium in genomic stability. Mutat Res. 2001; 475:113-121.

11. Creedon A, Flynn A, Cashman K. The effect of moderately and severely restricted dietary magnesium intakes on bone composition and bone metabolism in the rat. Br J Nutr. 1999;82:63-71.

12. Belluci MM, Giro G, del Barrio RAL, Pereira RMR, Marcantonio E, Orrico SRP. Effects of magnesium intake deficiency on bone metabolism and bone tissue around osseointegrated implants. Clin Oral Implants Res. 2011;22:716-721.

13. Toba Y, Kajita Y, Masuyama R, Takada Y, Suzuki K, Aoe S. Dietary magnesium supplementation affects bone metabolism and dynamic strength of bone in ovariectomized rats. $J$ Nutr. 2000;130:216-220.

14. Del Barrio RAL, Giro G, Belluci MM, et al. Effect of severe dietary magnesium deficiency on systemic bone density and removal torque of osseointegrated implants. Int J Oral Maxillofac Implants. 2010;25: $1125-1130$.

15. Hussain A, Bessho K, Takahashi K, Tabata Y. Magnesium calcium phosphate as a novel component enhances mechanical/physical properties of gelatin scaffold and osteogenic differentiation of bone marrow mesenchymal stem cells. Tissue Eng Part A. 2012;18:768-774.

16. Zheng YF, Gu XN, Xi YL, Chai DL. In vitro degradation and cytotoxicity of $\mathrm{Mg} / \mathrm{Ca}$ composites produced by powder metallurgy. Acta Biomater. 2010;6:1783-1791

17. Salunke P, Shanov V, Witte F. High purity biodegradable magnesium coating for implant application. Mater Sci Eng. 2011;176:1711-1717.

18. Gu XN, Zhou WR, Zheng YF, et al. Corrosion fatigue behaviors of two biomedical Mg alloys - AZ91D and WE43 - in simulated body fluid. Acta Biomater. 2010;6:4605-4613.

19. Willumeit R, Fischer J, Feyerabend F, et al. Chemical surface alteration of biodegradable magnesium exposed to corrosion media. Acta Biomater. 2011;7:2704-2715.

20. Lee JY, Han G, Kim YC, et al. Effects of impurities on the biodegradation behavior of pure magnesium. Met Mater Int. 2009;15:955-961.

21. Weng L, Webster TJ. Increased osteoblast functions on nanostructured magnesium. Nanotechnology. 2012;23:485105.

22. Witte F, Ulrich H, Palm C, Willbold E. Biodegradable magnesium scaffolds: Part II: peri-implant bone remodeling. J Biomed Mater Res A. 2007;81A:757-765.

23. Atrens A, Liu M, Zainal Abidin NI. Corrosion mechanism applicable to biodegradable magnesium implants. Mater Sci Eng B. 2011;176: 1609-1636.

24. Price RL, Ellison K, Haberstroh KM, Webster TJ. Nanometer surface roughness increases select osteoblast adhesion on carbon nanofiber compacts. J Biomed Mater Res A. 2004;70A:129-138.

25. Price R, Haberstroh K, Webster T. Enhanced functions of osteoblasts on nanostructured surfaces of carbon and alumina. Med Biol Eng Comput. 2003;41:372-375.

26. Liu HN, Slamovich EB, Webster TJ. Increased osteoblast functions on nanophase titania dispersed in poly-lactic-co-glycolic acid composites. Nanotechnology. 2005;16:S601-S608.

27. Zhang LJ, Ramsaywack S, Fenniri H, Webster TJ. Enhanced osteoblast adhesion on self-assembled nanostructured hydrogel scaffolds. Tissue Eng Part A. 2008;14:1353-1364.
International Journal of Nanomedicine

\section{Publish your work in this journal}

The International Journal of Nanomedicine is an international, peerreviewed journal focusing on the application of nanotechnology in diagnostics, therapeutics, and drug delivery systems throughout the biomedical field. This journal is indexed on PubMed Central, MedLine, CAS, SciSearch ${ }^{\circledR}$, Current Contents ${ }^{\circledR} /$ Clinical Medicine,

\section{Dovepress}

Journal Citation Reports/Science Edition, EMBase, Scopus and the Elsevier Bibliographic databases. The manuscript management system is completely online and includes a very quick and fair peer-review system, which is all easy to use. Visit http://www.dovepress.com/ testimonials.php to read real quotes from published authors. 